4

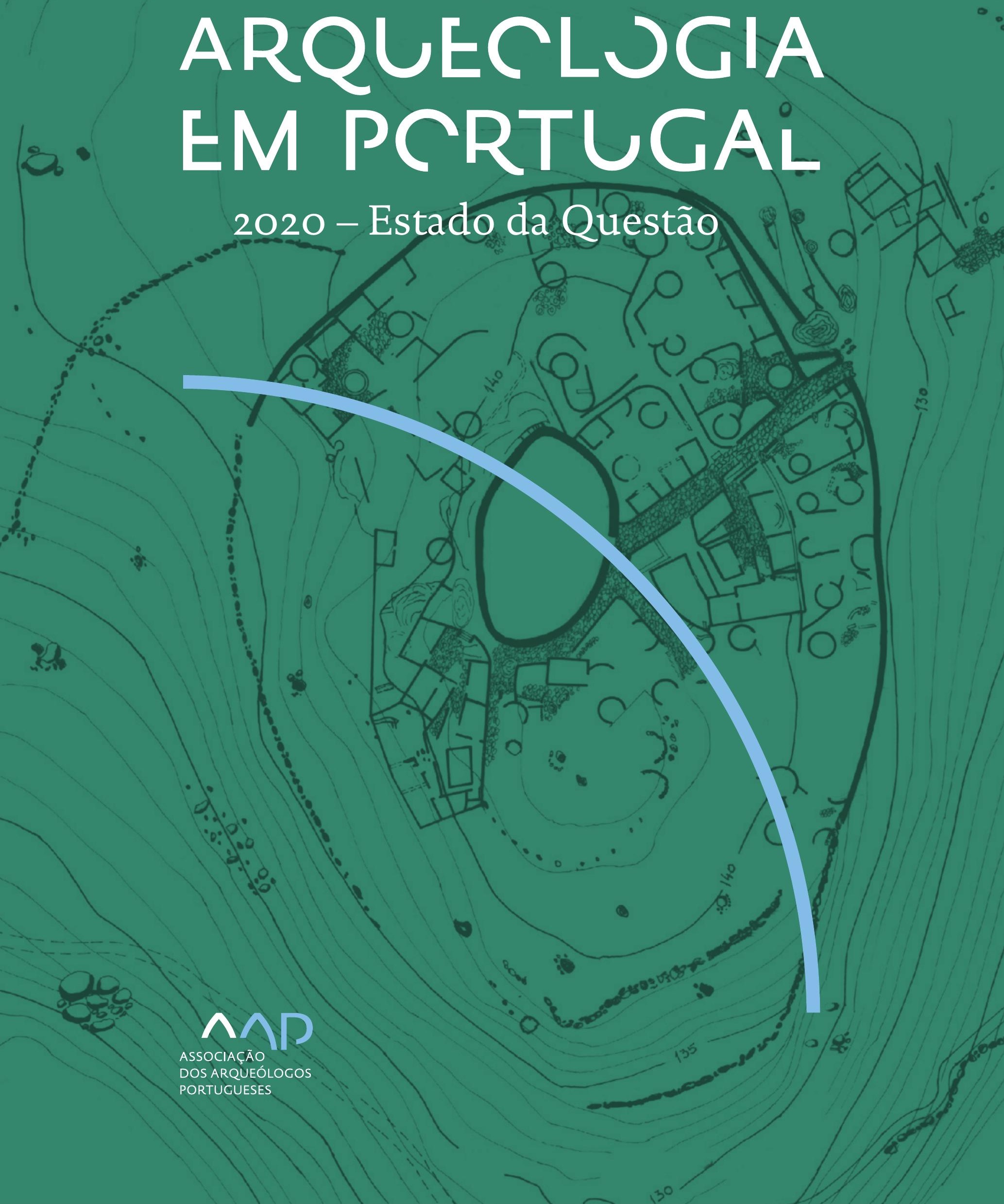


Coordenação editorial: José Morais Arnaud, César Neves e Andrea Martins Design gráfico: Flatland Design

AAP - ISBN: 978-972-9451-89-8

CITCEM - ISBN: 978-989-8970-25-1

Associação dos Arqueólogos Portugueses e CITCEM

Lisboa, 2020

O conteúdo dos artigos é da inteira responsabilidade dos autores. Sendo assim a Associação dos Arqueólogos Portugueses declina qualquer responsabilidade por eventuais equívocos ou questões de ordem ética e legal.

Desenho de capa:

Planta do castro de Monte Mozinho (Museu Municipal de Penafiel).

\section{$\hat{\wedge} \mathrm{P}$}

DOS ARQUEÓLOGOS PORTUGUESES

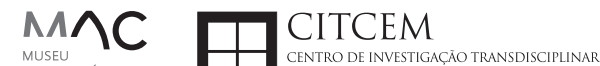
MUSEU
ARQUELLÓGICO
DO CARMO
U.PORTO

FLUP FACULDADE DE LETRAS
UNIVERSIDADE DO PORTO

Apoio

EC para a Ciência 


\section{Índice}

15 Prefácio

José Morais Arnaud

\section{Historiografia e Teoria}

17 Território, comunidade, memória e emoção: a contribuição da história da arqueologia (algumas primeiras e breves reflexões)

Ana Cristina Martins

25 Como descolonizar a arqueologia portuguesa?

Rui Gomes Coelho

41 Arqueologia e Modernidade: uma revisitação pessoal e breve de alguns aspetos da obra homónima de Julian Thomas de 2004

Vítor Oliveira Jorge

57 Dados para a História das Mulheres na Arqueologia portuguesa, dos finais do século XIX aos inícios do século XX: números, nomes e tabelas

Filipa Dimas / Mariana Diniz

73 Retractos da arqueologia portuguesa na imprensa: (in)visibilidades no feminino

Catarina Costeira / Elsa Luís

85 Arqueologia e Arqueólogos no Norte de Portugal Jacinta Bugalhão

101 Vieira Guimarães (1864-1939) e a arqueologia em Tomar: uma abordagem sobre o território e as gentes

João Amendoeira Peixoto / Ana Cristina Martins

115 Os memoráveis? A arqueologia algarvia na imprensa nacional e regional na presente centúria (2001-2019): características, visões do(s) passado(s) e a arqueologia

enquanto marca

Frederico Agosto / João Silva

129 A Evolução da Arqueologia Urbana e a Valorização Patrimonial no Barlavento Algarvio: Os casos de Portimão e Silves

Artur Mateus / Diogo Varandas / Rafael Boavida

\section{Gestão, Valorização e Salvaguarda do Património}

145 O Caderno Reivindicativo e as condições de trabalho em Arqueologia Miguel Rocha / Liliana Matias Carvalho / Regis Barbosa / Mauro Correia / Sara Simões / Jacinta Bugalhão / Sara Brito / Liliana Veríssimo Carvalho / Richard Peace / Pedro Peça / Cézer Santos

155 Os Estudos de Impacte Patrimonial como elemento para uma estratégia sustentável de minimização de impactes no âmbito de reconversões agrícolas Tiago do Pereiro

165 Salvaguarda de Património arqueológico em operações florestais: gestão e sensibilização Filipa Bragança / Gertrudes Zambujo / Sandra Lourenço / Belém Paiva / Carlos Banha / Frederico Tatá Regala / Helena Moura / Jacinta Bugalhão / João Marques / José Correia / Pedro Faria / Samuel Melro

179 Os valores do Património: uma investigação sobre os Sítios Pré-históricos de Arte Rupestre do Vale do Rio Côa e de Siega Verde José Paulo Francisco 
189 Conjugando recursos arqueológicos e naturais para potenciar as visitas ao Geoparque Litoral de Viana do Castelo (Noroeste de Portugal)

Hugo A. Sampaio / Ana M.S. Bettencourt / Susana Marinho / Ricardo Carvalhido

203 Áreas de Potencial Arqueológico na Região do Médio Tejo: Modelo Espacial Preditivo Rita Ferreira Anastácio / Ana Filipa Martins / Luiz Oosterbeek

223 Património Arqueológico e Gestão Territorial: O contributo da Arqueologia para a revisão do PDM de Avis

Ana Cristina Ribeiro

237 A coleção arqueológica do extinto Museu Municipal do Porto - Origens, Percursos e Estudos

Sónia Couto

251 Valpaços - uma nova carta arqueológica

Pedro Pereira / Maria de Fátima Casares Machado

263 Arqueologia na Cidade de Peniche

Adriano Constantino / Luís Rendeiro

273 Arqueologia Urbana: a cidade de Lagos como caso de Estudo Cátia Neto

285 Estratégias de promoção do património cultural subaquático nos Açores. O caso da ilha do Faial

José Luís Neto / José Bettencourt / Luís Borges / Pedro Parreira

297 Carta Arqueológica da Cidade Velha: Uma primeira abordagem

Jaylson Monteiro / Nireide Tavares / Sara da Veiga / Claudino Ramos / Edson Brito /

Carlos Carvalho / Francisco Moreira / Adalberto Tavares

311 Antropologia Virtual: novas metodologias para a análise morfológica e funcional Ricardo Miguel Godinho / Célia Gonçalves

\section{Didáctica da Arqueologia}

327 Como os projetos de Arqueologia podem contribuir para uma comunidade culturalmente mais consciente Alexandra Figueiredo / Claúdio Monteiro / Adolfo Silveira / Ricardo Lopes

337 Educação Patrimonial - Um cidadão esclarecido é um cidadão ativo! Ana Paula Almeida

351 A aproximação da Arqueologia à sala de aula: um caso de estudo no $3^{\circ}$ ciclo do Ensino Básico Luís Serrão Gil

363 Arqueologia 3.o - Pensar e comunicar a Arqueologia para um futuro sustentável Mónica Rolo

377 “Conversa de Arqueólogos" - Divulgar a Arqueologia em tempos de Pandemia Diogo Teixeira Dias

389 Escola Profissional de Arqueologia: desafios e oportunidades Susana Nunes / Dulcineia Pinto / Júlia Silva / Ana Mascarenhas

399 Os Museus de Arqueologia e os Jovens: a oferta educativa para o público adolescente Beatriz Correia Barata / Leonor Medeiros

411 O museu universitário como mediador entre a ciência e a sociedade: o exemplo da secção de arqueologia no Museu de História Natural e da Ciência da Universidade do Porto (MHNC-UP)

Rita Gaspar 
421 Museu de Lanifícios: Real Fábrica de Panos. Atividades no âmbito da Arqueologia Beatriz Correia Barata / Rita Salvado

427 Arqueologia Pública e o caso da localidade da Mata (Torres Novas) Cláudia Manso / Ana Rita Ferreira / Cristiana Ferreira / Vanessa Cardoso Antunes

431 Do sítio arqueológico ao museu: um percurso (também) didático Lídia Fernandes

447 Estão todos convidados para a Festa! E para dançar também... O projecto do Serviço Educativo do Museu Arqueológico do Carmo na $5^{\underline{a}}$ Edição da Festa da Arqueologia Rita Pires dos Santos

459 O “Clã de Carenque”, um projeto didático de arqueologia Eduardo Gonzalez Rocha

469 Mediação cultural: peixe que puxa carroça nas Ruínas Romanas de Troia Inês Vaz Pinto / Ana Patrícia Magalhães / Patrícia Brum / Filipa Santos

481 Didática Arqueológica, experiências do Projeto Mértola Vila Museu Maria de Fátima Palma / Clara Rodrigues / Susana Gómez / Lígia Rafael

\section{Arte Rupestre}

497 Os inventários de arte rupestre em Portugal Mila Simões de Abreu

513 O projeto FIRST-ART - conservação, documentação e gestão das primeiras manifestações de arte rupestre no Sudoeste da Península Ibérica: as grutas do Escoural e Maltravieso Sara Garcês / Hipólito Collado / José Julio García Arranz / Luiz Oosterbeek / António Carlos Silva / Pierluigi Rosina / Hugo Gomes / Anabela Borralheiro Pereira / George Nash / Esmeralda Gomes / Nelson Almeida / Carlos Carpetudo

523 Trabalhos de documentação de arte paleolítica realizados no âmbito do projeto PalæoCôa André Tomás Santos / António Fernando Barbosa / Luís Luís / Marcelo Silvestre / Thierry Aubry

537 Imagens fantasmagóricas, silhuetas elusivas: as figuras humanas na arte do Paleolítico Superior da região do Côa Mário Reis

$55^{1}$ Os motivos zoomórficos representados nas placas de tear de Vila Nova de São Pedro (Azambuja, Portugal) Andrea Martins / César Neves / José M. Arnaud / Mariana Diniz

571 Arte Rupestre do Monte de Góios (Lanhelas, Caminha). Síntese dos resultados dos trabalhos efectuados em 2007-2009 Mário Varela Gomes

599 Gravuras rupestres de barquiformes no Monte de S. Romão, Guimarães, Noroeste de Portugal Daniela Cardoso

613 Círculos segmentados gravados na Bacia do Rio Lima (Noroeste de Portugal): contributos para o seu estudo Diogo Marinho / Ana M.S. Bettencourt / Hugo Aluai Sampaio

631 Equídeos gravados no curso inferior do Rio Mouro, Monção (NW Portugal). Análise preliminar Coutinho, L.M. / Bettencourt, A.M.S / Sampaio, Hugo A.S

645 Paletas na Arte Rupestre do Noroeste de Portugal. Inventário preliminar Bruna Sousa Afonso / Ana M. S. Bettencourt / Hugo A. Sampaio 


\section{Pré-História}

661 O projeto Miño/Minho: balanço de quatro anos de trabalhos arqueológicos Sérgio Monteiro-Rodrigues / João Pedro Cunha-Ribeiro / Eduardo Méndez-Quintas / Carlos Ferreira / Pedro Xavier / José Meireles / Alberto Gomes / Manuel Santonja / Alfredo Pérez-González

677 A ocupação paleolítica da margem esquerda do Baixo Minho: a indústria lítica do sítio de Pedreiras 2 (Monção, Portugal) e a sua integração no contexto regional Carlos Ferreira / João Pedro Cunha-Ribeiro / Sérgio Monteiro-Rodrigues / Eduardo Méndez-Quintas / Pedro Xavier / José Meireles / Alberto Gomes / Manuel Santonja / Alfredo Pérez-González

693 O sítio acheulense do Plistocénico médio da Gruta da Aroeira Joan Daura / Montserrat Sanz / Filipa Rodrigues / Pedro Souto / João Zilhão

703 As sociedades neandertais no Barlavento algarvio: modelos preditivos com recurso aos SIG

Daniela Maio

715 A utilização de quartzo durante o Paleolítico Superior no território dos vales dos rios Vouga e Côa

Cristina Gameiro / Thierry Aubry / Bárbara Costa / Sérgio Gomes / Luís Luís / Carmen Manzano / André Tomás Santos

733 Uma perspetiva diacrónica da ocupação do concheiro do Cabeço da Amoreira (Muge, Portugal) a partir da tecnologia lítica Joana Belmiro / João Cascalheira / Célia Gonçalves

745 Novos dados sobre a Pré-história Antiga no concelho de Palmela. A intervenção arqueológica no sítio do Poceirão I

Michelle Teixeira Santos

757 Problemas em torno de Datas Absolutas Pré-Históricas no Norte do Alentejo Jorge de Oliveira

771 Povoamento pré-histórico nas áreas montanhosas do NO de Portugal: o Abrigo 1 de Vale de Cerdeira Pedro Xavier / José Meireles / Carlos Alves

783 Apreciação do povoamento do Neolítico Inicial na Baixa Bacia do Douro. A Lavra I (Serra da Aboboreira) como caso de estudo Maria de Jesus Sanches

797 O Processo de Neolitização na Plataforma do Mondego: os dados do Sector C do Outeiro dos Castelos de Beijós (Carregal do Sal)

João Carlos de Senna-Martinez / José Manuel Quintã Ventura / Andreia Carvalho / Cíntia Maurício

823 Novos trabalhos na Lapa da Bugalheira (Almonda, Torres Novas) Filipa Rodrigues / Pedro Souto / Artur Ferreira / Alexandre Varanda / Luís Gomes / Helena Gomes / João Zilhão

837 A pedra polida e afeiçoada do sítio do Neolítico médio da Moita do Ourives (Benavente, Portugal)

César Neves

857 Casal do Outeiro (Encarnação, Mafra): novos contributos para o conhecimento do povoamento do Neolítico final na Península de Lisboa.

Cátia Delicado / Carlos Maneira e Costa / Marta Miranda / Ana Catarina Sousa

873 Stresse infantil, morbilidade e mortalidade no sítio arqueológico do Neolítico Final/ Calcolítico ( $4^{\circ}$ e $3^{\circ}$ milénio a.C.) do Monte do Carrascal 2 (Ferreira do Alentejo, Beja) Liliana Matias de Carvalho / Sofia N. Wasterlain 
885 Come together: O Conjunto Megalítico das Motas (Monção, Viana do Castelo) e as expressões Campaniformes do Alto Minho Ana Catarina Basílio / Rui Ramos

899 Trabalhos arqueológicos no sítio Calcolítico da Pedreira do Poio Carla Magalhães / João Muralha / Mário Reis / António Batarda Fernandes

913 O sítio arqueológico de Castanheiro do Vento. Da arquitectura do sítio à arquitectura de um território João Muralha Cardoso

925 Estudo zooarqueológico das faunas do Calcolítico final de Vila Nova de São Pedro (Azambuja, Portugal): Campanhas de 2017 e 2018 Cleia Detry / Ana Catarina Francisco / Mariana Diniz / Andrea Martins / César Neves / José Morais Arnaud

943 As faunas depositadas no Museu Arqueológico do Carmo provenientes de Vila Nova de São Pedro (Azambuja): as campanhas de 1937 a 1967 Ana Catarina Francisco / Cleia Detry / César Neves / Andrea Martins / Mariana Diniz / José Morais Arnaud

959 Análise funcional de material lítico em sílex do castro de Vila Nova de S. Pedro (Azambuja, Portugal): uma primeira abordagem Rafael Lima

971 O recinto da Folha do Ouro 1 (Serpa) no contexto dos recintos de fossos calcolíticos alentejanos

António Carlos Valera / Tiago do Pereiro / Pedro Valério / António M. Monge Soares

\section{Proto-História}

987 Produção de sal marinho na Idade do Bronze do noroeste Português. Alguns dados para uma reflexão

Ana M. S. Bettencourt / Sara Luz / Nuno Oliveira / Pedro P. Simões / Maria Isabel C. Alves / Emílio Abad-Vidal

1001 A estátua-menir do Pedrão ou de São Bartolomeu do Mar (Esposende, noroeste de Portugal) no contexto arqueológico da fachada costeira de entre os rios Neiva e Cávado Ana M. S. Bettencourt / Manuel Santos-Estévez / Pedro Pimenta Simões / Luís Gonçalves

1015 O Castro do Muro (Vandoma/Baltar, Paredes) - notas para uma biografia de ocupação da Idade do Bronze à Idade Média

Maria Antónia D. Silva / Ana M. S. Bettencourt / António Manuel S. P. Silva / Natália Félix

1031 Do Bronze Final à Idade Média - continuidades e hiatos na ocupação de Povoados em Oliveira de Azeméis João Tiago Tavares / Adriaan de Man

1041 As faunas do final da Idade do Bronze no Sul de Portugal: leituras desde o Outeiro do Circo (Beja)

Nelson J. Almeida / Íris Dias / Cleia Detry / Eduardo Porfírio / Miguel Serra

1055 A Espada do Monte das Oliveiras (Serpa) - uma arma do Bronze Pleno do Sudoeste Rui M. G. Monge Soares / Pedro Valério / Mariana Nabais / António M. Monge Soares

1065 São Julião da Branca (Albergaria-a-Velha) - Investigação e valorização de um povoado do Bronze Final

António Manuel S. P. Silva / Paulo A. P. Lemos / Sara Almeida e Silva / Edite Martins de Sá

1083 Do castro de S. João ao Mosteiro de Santa Clara: notícia de uma intervenção arqueológica, em Vila do Conde Rui Pinheiro 
1095 O castro de Ovil (Espinho), um quarto de século de investigação - resultados e questões em aberto

Jorge Fernando Salvador / António Manuel S. P. Silva

1111 O Castro de Salreu (Estarreja), um povoado proto-histórico no litoral do Entre Douro e Vouga

Sara Almeida e Silva / António Manuel S. P. Silva / Paulo A. P. Lemos / Edite Martins de Sá

1127 Castro de Nossa Senhora das Necessidades (Sernancelhe): uma primeira análise artefactual Telma Susana O. Ribeiro

${ }_{1141}$ A cividade de Bagunte. O estado atual da investigação Pedro Brochado de Almeida

1153 Zoomorfos na cerâmica da Idade do Ferro no NW Peninsular: inventário, cronologias e significado Nuno Oliveira / Cristina Seoane

1163 Vasos gregos em Portugal: diferentes maneiras de contar a história do intercâmbio cultural na Idade do Ferro

Daniela Ferreira

1175 Os exotica da necrópole da Idade do Ferro do Olival do Senhor dos Mártires (Alcácer do Sal) no seu contexto regional

Francisco B. Gomes

\section{Antiguidade Clássica e Tardia}

1191 O uso de madeira como combustível no sítio da Quinta de Crestelos (Baixo Sabor): da Idade do Ferro à Romanização Filipe Vaz / João Tereso / Sérgio Simões Pereira / José Sastre / Javier Larrazabal Galarza / Susana Cosme / José António Pereira / Israel Espi

1207 Cultivos de Época Romana no Baixo Sabor: continuidade em tempos de mudança? João Pedro Tereso / Sérgio Simões Pereira / Filipe Santos / Luís Seabra / Filipe Vaz

1221 A casa romana na Hispânia: aplicação dos modelos itálicos nas províncias ibéricas Fernanda Magalhães / Diego Machado / Manuela Martins

1235 As pinturas murais romanas da Rua General Sousa Machado, n. ${ }^{5}$ 1, Chaves José Carvalho

1243 Trás do Castelo (Vale de Mir, Pegarinhos, Alijó) - Uma exploração agrícola romana do Douro

Tony Silvino / Pedro Pereira

1255 A sequência de ocupação no quadrante sudeste de Bracara Augusta: as transformações de uma unidade doméstica Lara Fernandes / Manuela Martins

1263 Os Mosaicos com decoração geométrica e geométrico-vegetalista dos sítios arqueológicos da área do Conuentus Bracaraugustanus. Novas abordagens quanto à conservação, restauro, decoração e datação Maria de Fátima Abraços / Licínia Wrench

1277 “Casa Romana” do Castro de São Domingos (Cristelos, Lousada): Escavação, Estudo e Musealização Paulo André de P. Lemos

1291 A arqueobotânica no Castro de Guifões (Matosinhos, Noroeste de Portugal): O primeiro estudo carpológico

Luís Seabra / Andreia Arezes / Catarina Magalhães / José Varela / João Pedro Tereso 
1305 Um Horreum Augustano na Foz do Douro (Monte do Castelo de Gaia, Vila Nova de Gaia) Rui Ramos

1311 Ponderais romanos na Lusitânia: padrões, formas, materiais e contextos de utilização Diego Barrios Rodríguez

1323 Um almofariz centro-itálico na foz do Mondego

Marco Penajoia

1335 Estruturas romanas de Carnide - Lisboa Luísa Batalha / Mário Monteiro / Guilherme Cardoso

1347 O contexto funerário do sector da "necrópole NO" da Rua das Portas de S. Antão (Lisboa): o espaço, os artefactos, os indivíduos e a sua interconectividade na interpretação do passado Sílvia Loja, José Carlos Quaresma, Nelson Cabaço, Marina Lourenço, Sílvia Casimiro, Rodrigo Banha da Silva, Francisca Alves-Cardoso

${ }_{1361}$ Povoamento em época Romana na Amadora - resultados de um projeto pluridisciplinar Gisela Encarnação / Vanessa Dias

1371 A Arquitectura Residencial em Mirobriga (Santiago do Cacém): contributo a partir de um estudo de caso Filipe Sousa / Catarina Felício

${ }_{1385}$ O fim do ciclo. Saneamento e gestão de resíduos nos edifícios termais de Mirobriga (Santiago do Cacém)

Catarina Felício / Filipe Sousa

1399 Balsa, Topografia e Urbanismo de uma Cidade Portuária Vítor Silva Dias / João Pedro Bernardes / Celso Candeias / Cristina Tété Garcia

1413 No Largo das Mouras Velhas em Faro (2017): novas evidências da necrópole norte de Ossonoba e da sua ocupação medieval Ricardo Costeira da Silva / Paulo Botelho / Fernando Santos / Liliana Nunes

1429 Instrumentos de pesca recuperados numa fábrica de salga em Ossonoba (Faro) Inês Rasteiro / Ricardo Costeira da Silva / Paulo Botelho

1439 A Necrópole Romana do Eirô, Duas Igrejas (Penafiel): intervenção arqueológica de 2016 Laura Sousa / Teresa Soeiro

1457 Ritual, descarte ou afetividade? A presença de Canis lupus familiaris na Necrópole Noroeste de Olisipo (Lisboa)

Beatriz Calapez Santos / Sofia Simões Pereira / Rodrigo Banha da Silva / Sílvia Casimiro / Cleia Detry / Francisca Alves Cardoso

1467 Dinâmicas económicas em Bracara na Antiguidade Tardia Diego Machado / Manuela Martins / Fernanda Magalhães / Natália Botica

1479 Cerâmicas e Vidros da Antiguidade Tardia do Edifício sob a Igreja do Bom Jesus (Vila Nova de Gaia) Joaquim Filipe Ramos

1493 Novos contributos para a topografia histórica de Mértola no período romano e na Antiguidade Tardia Virgílio Lopes

\section{8. Época Medieval}

1511 Cerâmicas islâmicas no Garb setentrional "português": algumas evidências e incógnitas Constança dos Santos / Helena Catarino / Susana Gómez / Maria José Gonçalves / Isabel Inácio / Gonçalo Lopes / Jacinta Bugalhão / Sandra Cavaco / Jaquelina Covaneiro / Isabel Cristina Fernandes / Ana Sofia Gomes 
1525 Contributo para o conhecimento da cosmética islâmica, em Silves, durante a Idade Média Rosa Varela Gomes

1537 Yábura e o seu território - uma análise histórico-arqueológica de Évora entre os séculos VIII-XII José Rui Santos

1547 A encosta sul do Castelo de Palmela - resultados preliminares da escavação arqueológica Luís Filipe Pereira / Michelle Teixeira Santos

1559 A igreja de São Lourenço (Mouraria, Lisboa): um conjunto de silos e de cerâmica medieval islâmica

Andreia Filipa Moreira Rodrigues

1571 O registo material de movimentações populacionais no Médio Tejo, durante os séculos XII-XIII. Dois casos de "sunken featured buildings", nos concelhos de Cartaxo e Torres Novas Marco Liberato / Helena Santos / Nuno Santos

1585 O nordeste transmontano nos alvores da Idade média. Notas para reflexão Ana Maria da Costa Oliveira

1601 Sepulturas escavadas na rocha do Norte de Portugal e do Vale do Douro: primeiros resultados do Projecto SER-NPVD

Mário Jorge Barroca / César Guedes / Andreia Arezes / Ana Maria Oliveira

1619 "Portucalem Castrum Novum" entre o Mediterrâneo e o Atlântico: o estudo dos materiais cerâmicos alto-medievais do arqueossítio da rua de D. Hugo, nํ. 5 (Porto) João Luís Veloso

1627 A Alta Idade Média na fronteira de Lafões: notas preliminares sobre a Arqueologia no Concelho de Vouzela

Manuel Luís Real / Catarina Tente

1641 Um conjunto cerâmico medieval fora de portas: um breve testemunho aveirense Susana Temudo

${ }_{1651}$ Os Lóios do Porto: uma perspetiva integrada no panorama funerário da Baixa Idade Média à Época Moderna em meios urbanos em Portugal

Ana Lema Seabra

1659 O Caminho Português Interior de Santiago como eixo viário na Idade Média Pedro Azevedo

1665 Morfologia Urbana: Um exercício em torno do Castelo de Ourém André Donas-Botto / Jaqueline Pereira

1677 Intervenção arqueológica na Rua Marquês de Pombal/Largo do Espírito Santo (Bucelas, Loures)

Florbela Estêvão / Nathalie Antunes-Ferreira / Dário Ramos Neves / Inês Lisboa

1691 O Cemitério Medieval do Poço do Borratém e a espacialidade funerária na cidade de Lisboa Inês Belém / Vanessa Filipe / Vasco Noronha Vieira / Sónia Ferro / Rodrigo Banha da Silva

1705 Um Espaço Funerário Conventual do séc. XV em Lisboa: o caso do Convento de São Domingos da Cidade Sérgio Pedroso / Sílvia Casimiro / Rodrigo Banha da Silva / Francisca Alves Cardoso

\section{9. Época Moderna e Contemporânea}

1721 Arqueologia Moderna em Portugal: algumas reflexões críticas em torno da quantificação de conjuntos cerâmicos e suas inferências históricas e antropológicas Rodrigo Banha da Silva / André Bargão / Sara da Cruz Ferreira

1733 Faianças de dois contextos entre os finais do século XVI e XVIII do Palácio dos Condes de Penafiel, Lisboa

Martim Lopes / Tomás Mesquita 
1747 Um perfil de consumo do século XVIII na foz do Tejo: O caso do Mercado da Ribeira, Lisboa Sara da Cruz Ferreira / Rodrigo Banha da Silva / André Bargão

1761 Os Cachimbos dos Séculos XVII e XVIII do Palácio Mesquitela e Convento dos Inglesinhos (Lisboa)

Inês Simão / Marina Pinto / João Pimenta / Sara da Cruz Ferreira / André Bargão / Rodrigo Banha da Silva

1775 "Tomar os fumos da erua que chamão em Portugal erua sancta». Estudo de Cachimbos provenientes da Rua do Terreiro do Trigo, Lisboa

Miguel Martins de Sousa / José Pedro Henriques / Vanessa Galiza Filipe

1787 Cachimbos de Barro Caulínitico da Sé da Cidade Velha (República de Cabo Verde)

Rodrigo Banha da Silva / João Pimenta / Clementino Amaro

1801 Algumas considerações sobre espólio não cerâmico recuperado no Largo de Jesus (Lisboa) Carlos Boavida

1815 Adereços de vidro, dos séculos XVI-XVIII, procedentes do antigo Convento de Santana de Lisboa (anéis, braceletes e contas)

Joana Gonçalves / Rosa Varela Gomes / Mário Varela Gomes

1837 Da ostentação, luxo e poder à simplicidade do uso quotidiano: arqueologia e simbologia de joias e adornos da Idade Moderna Portuguesa Jéssica Iglésias

1849 Os amuletos em Portugal - dos objetos às superstições: o coral vermelho Alexandra Vieira

1865 Cerâmicas de Vila Franca de Xira nos séculos XV e XVI Eva Pires

1879 «Não passa por teu o que me pertence». Marcas de individualização associadas a faianças do Convento de Nossa Senhora de Aracoeli, Alcácer do Sal Catarina Parreira / Íris Fragoso / Miguel Martins de Sousa

1891 Cerâmica de Leiria: alguns focos de produção

Jaqueline Pereira / André Donas-Botto

1901 Os Fornos na Rua da Biquinha, em Óbidos Hugo Silva / Filipe Oliveira

1909 A casa de Pêro Fernandes, contador dos contos de D. Manuel I: o sítio arqueológico da Silha do Alferes, Seixal (século XVI) Mariana Nunes Ferreira

1921 O Alto da Vigia (Sintra) e a vigilância e defesa da costa Alexandre Gonçalves / Sandra Santos

1937 O contexto da torre sineira da Igreja de Santa Maria de Loures Paulo Calaveira / Martim Lopes

1949 A Necrópole do Hospital Militar do Castelo de São Jorge e as práticas funerárias na Lisboa de Época Moderna Susana Henriques / Liliana Matias de Carvalho / Ana Amarante / Sofia N. Wasterlain

1963 SAND - Sarilhos Grandes Entre dois Mundos: o adro da Igreja e a Paleobiologia dos ossos humanos recuperados

Paula Alves Pereira / Roger Lee Jesus / Bruno M. Magalhães

1975 Expansão urbana da vila de Cascais no século XVII e XVIII: a intervenção arqueológica na Rua da Vitória no 15 a 17

Tiago Pereira / Vanessa Filipe

1987 Novos dados para o conhecimento do Urbanismo de Faro em época Moderna Ana Rosa 
1995 Um exemplo de Arqueologia Urbana em Alcoutim: o Antigo Edifício dos CTT Marco Fernandes / Marta Dias / Alexandra Gradim / Virgílio Lopes / Susana Gómez Martínez

2007 Palácio dos Ferrazes (Rua das Flores/Rua da Vitória, Porto): a cocheira de Domingos Oliveira Maia

Francisco Raimundo

2021 As muitas vidas de um edifício urbano: História, Arqueologia e Antropologia no antigo Recreatório Paroquial de Penafiel Helena Bernardo / Jorge Sampaio / Marta Borges

2035 O convento de Nossa Senhora da Esperança de Ponta Delgada: o contributo da arqueologia para o conhecimento de um monumento identitário João Gonçalves Araújo / N’Zinga Oliveira

2047 Arqueologia na ilha do Corvo... em busca da capela de Nossa Senhora do Rosário Tânia Manuel Casimiro / José Luís Neto / Luís Borges / Pedro Parreira

2059 Perdidos à vista da Costa. Trabalhos arqueológicos subaquáticos na Barra do Tejo Jorge Freire / José Bettencourt / Augusto Salgado

2071 Arqueologia marítima em Cabo Verde: enquadramento e primeiros resultados do projecto CONCHA

José Bettencourt / Adilson Dias / Carlos Lima / Christelle Chouzenoux / Cristóvão Fonseca / Dúnia Pereira / Gonçalo Lopes / Inês Coelho / Jaylson Monteiro / José Lima / Maria Eugénia Alves / Patrícia Carvalho / Tiago Silva

2085 Trabalhos arqueológicos na Cidade Velha (Ribeira Grande de Santiago, Cabo Verde): reflexões sobre um projecto de investigação e divulgação patrimonial André Teixeira / Jaylson Monteiro / Mariana Mateus / Nireide Tavares / Cristovão Fonseca / Gonçalo C. Lopes / Joana Bento Torres / Dúnia Pereira / André Bargão / Aurélie Mayer / Bruno Zélie / Carlos Lima / Christelle Chouzenoux / Inês Henriques / Inês Pinto Coelho / José Lima / Patrícia Carvalho / Tiago Silva

2103 A antiga fortificação de Quelba / Khor Kalba (E.A.U.). Resultados de quatro campanhas de escavações, problemáticas e perspectivas futuras Rui Carita / Rosa Varela Gomes / Mário Varela Gomes / Kamyar Kamyad

2123 Colónias para homens novos: arqueologia da colonização agrária fascista no noroeste ibérico Xurxo Ayán Vila / José Mạ . Señorán Martín 


\title{
CERÂMICAS E VIDROS DA ANTIGUIDADE TARDIA DO EDIFÍCIO SOB A IGREJA DO BOM JESUS (VILA NOVA DE GAIA)
}

\author{
Joaquim Filipe Ramos
}

\begin{abstract}
RESUMO
Nos finais do séc. XX, as escavações arqueológicas realizadas na Igreja do Bom Jesus de Gaia fizeram surgir mais um ponto de história no município de Vila Nova de Gaia, com o levantamento de um amplo espólio arqueológico, datável desde o séc. V/VI até à época moderna. Até à data, o material recolhido só tinha sido parcialmente estudado, de forma a dar a conhecer os resultados das escavações. Como tal, era necessário um estudo, um pouco mais detalhado, sobre os materiais encontrados nestas intervenções.

Nesse sentido é aqui apresentado um estudo, desenvolvido em contexto de estágio académico, sobre os fabricos de sigillata, africana, hispânica e focense, e cerâmica cinzenta tardia, ou seja, os fabricos de cerâmica utilitária tardia, provenientes da igreja do Bom Jesus de Gaia, anexando ainda o estudo do vidro tardio, um material de igual versatilidade e ainda assim pouco estudado.

Palavras-chave: Bom Jesus de Gaia, Sigillata, Vidro tardio, Vila Nova de Gaia.
\end{abstract}

\begin{abstract}
At the end of the XX century, the archaeological survey carried out at the Bom Jesus de Gaia church, gave rise to another point of history in the city of Vila Nova de Gaia, with the survey of a wide archaeological collection dating back since the V/VI century, to the modern times.

Until now, the collected materials were only superficially studied, just to provide the first results of the excavations. As such a study a little more in depth was needed. In that sense we present here a study on the late roman pottery, the late grey ceramics, that is, the manufactures of late utilitarian ceramics from the church of Bom Jesus de Gaia, also enclosing the study of late glass, an equally versatile material and still a lot less studied. Keywords: Bom Jesus de Gaia, Late Roman Pottery, Late Grey Pottery, Late glass.
\end{abstract}

\section{LOCALIZAÇÃO E DESCRIÇÃO DO SÍTIO}

O edifício conhecido como igreja do Bom Jesus de Gaia ou igreja de Gaia ${ }^{1}$, atualmente designada por capela da Nossa Sra. da Bonança / capela do Bom Jesus de Gaia, foi escavada nos anos 1988/89 e 1992. Situa-se na interceção da rua Viterbo de Campos, para a qual está virada a sua fachada principal, com a rua do Prior, uma pequena ruela pedonal que dá acesso à fachada lateral da capela, orientada a Sul. $\mathrm{Na}$ fachada lateral que se encontra a Norte existe uma pequena viela apertada entre muros, de pedra e escadeada, que se encontra atualmente entaipada (GUIMARÃES, 1995).
O edifício religioso está assente num socalco artificial, que permite um melhor nivelamento do terreno. Tem 17,5 metros de comprimento máximo e 7,75 metros de largura no corpo principal do templo. A área de implantação é de 576 metros quadrados considerando o pequeno adro no lado norte e o largo do Prior a Sul (GUIMARÃES, 1995, pp.124 e segs.). É composta por dois corpos simples e justapostos, o da capela-mor e o corpo principal, ao qual estão adoçados a sacristia a sul e a torre sineira no lado norte. A torre está alinhada com a fachada principal e com uma pequena escada de acesso exterior acessível a partir do adro norte. Foi um edifício que ao longo dos tempos sofreu bastantes obras de amplia-

1. Designação considerada por GUIMARÃES, Gonçalves, Escavações Arqueológicas na Igreja de Gaia, Barcelona, 1995. 
ção e várias tentativas de melhoramento, mas que acabaram por o descaracterizar. Neste momento apresenta o aspeto de uma pequena igreja com uma frontaria da segunda metade do século XVII com uma torre sineira datável do século XVIII (GUIMARÃES, 1995, pp.124-130).

\section{RESULTADOS DAS ESCAVAÇÕES: ESTRUTURAS, ESTRATIGRAFIA E ESPÓLIO}

Estas escavações foram desenvolvidas durante campanhas realizadas pelo Gabinete de História e Arqueologia de Vila Nova de Gaia nos anos de 1988, 1989 e 1992, em seguimento da solicitação feita à Câmara Municipal de Vila Nova de Gaia, em 1987, para a realização de obras nesta igreja integrada no Centro Histórico (GUIMARÃES, 1995).

As escavações realizadas nos anos 1988 e 1989 permitiram perceber as sucessivas fases de construção, reconstrução e alteamento efetuadas no local (GUIMARÃES, 1988). A campanha de 1992 permitiu obter mais dados e tecer algumas considerações sobre as mais antigas fases de ocupação, paleocristãs e alti-medievais².

Sobre o afloramento granítico, a uma cota negativa de -2,50 metros do ponto o (que era o nível do soalho existente antes das intervenções), foram descobertas as ruínas daquele que teria sido um edifício paleocristão, violentamente destruído no século VI. Sobre este encontravam-se vestígios de um edifício alti-medieval, também violentamente destruído e incendiado. Por fim, no nível superior, coincidente com parte da igreja atual, foram identificados alguns segmentos de parede da Baixa Idade Média, sucessivamente alteados e reforçados ao longo das épocas moderna e contemporânea.

Nas ruínas paleocristãs encontra-se, nos já referidos 2,50 metros abaixo do alicerce da fachada atual, um muro com orientação NNE/SSO para o qual foi atribuída a designação $\mathrm{Mi}^{3}$ (ver Figura 1). Este travaria um socalco de saibro onde estão abertas sepulturas

2. Estes resultados estão bem descritos na obra de GUIMARÃES, Gonçalves 1995, Gaia e Vila Nova na Idade Média - Arqueologia de uma área ribeirinha Porto, Universidade Portucalense, o cerne de grande parte da informação para este trabalho.

3. Estas designações atribuídas estão presentes e assinaladas na Estampa XI - "Planta da Igreja de Gaia: área escavada” (GUIMARÃES, 1995) de uma época já posterior ao muro. Neste mesmo socalco de saibro está inserida uma escadaria de granito com cerca de 1,5 metros de largura, da qual se encontravam preservados quatro degraus. As escavações permitiram perceber que a escadaria terminaria a uma cota mais elevada pois existiam ainda vestígios do seu alinhamento. Os degraus que faltam teriam sido destruídos pela abertura das tais sepulturas anteriormente mencionadas, ou ainda para alinhar a grelha sepulcral de Época Moderna (GUIMARÃES, 1989). O muro estava bastante derrubado no lado SSO, devido ao rolamento de enormes blocos de granito, aos quais se atribui a causa da destruição violenta do edifício tardo-romano. A NNE o muro está melhor conservado, com mais de um metro de altura e de aparelho regular. Deste mesmo lado partia outro muro, designado $\mathrm{M}$, perpendicular ao Mi e que no sentido ONO/ESSE, prosseguia ultrapassando a sapata do arco triunfal terminando em ângulo reto já na área da capela-mor, com um total de 9 metros de comprimento. Desse ângulo arranca outro muro o $\mathrm{M}_{3}$ direcionado a NE que, ao contrário dos anteriores referidos formados por duas faces de parede aparelhada com enchimento interior, este era constituído por grandes lajes graníticas bem esquadriadas e aparelhadas interpretado como parte de parede de fachada ou pedestal de uma colunata, dado que foi encontrado neste lado da escavação, no entulhamento, um fuste partido. Neste canto, existe ainda um outro muro, M4, também constituído por grandes blocos graníticos aparelhados, paralelo ao muro $\mathrm{M}_{2}$, e que seria parte de uma parede interior (GUIMARÃES, 1995, p. 133) (Figura 1).

Cronologicamente estas ruínas estavam relacionadas com um extenso nível de tégula que cobriria toda a área disponível, sobre a qual se posicionava uma camada de entulhamento, formada por pedras do derrube da estrutura, mas também por grandes blocos graníticos que não faziam parte da construção existente. No estrato $03^{4}$, sob a tégula e tijoleiras, encontrou-se um vasto número de fragmentos de cerâmica importada e vidro datados do séc. VI (GUIMARÃES, 1995, p. 135).

O estudo da escavação e dos dados de cultura material, e neste caso particular da cerâmica e do vidro, permitiu constatar que os vestígios mais antigos

\footnotetext{
4. Designação atribuída a uma das camadas descritas na Estampa XII "Cortes longitudinal e transversal da área escavada da igreja de Gaia"
} 
correspondem a um edifício paleocristão, que terá sido destruído no último quartel do séc.VI, mas que teria sido construído ainda em período de ocupação romana (GUIMARÃES, 1995, p.135).

Foram recuperados cerca de 15000 fragmentos de cerâmica de todas épocas (GUIMARÃES, 1995, p. 135), dentro dos quais 842 correspondem sigillatas tardias de origem africana, foceense e hispânica, e a cinzenta tardia ${ }^{5}$, com 650 fragmentos. Deste conjunto, convém destacar duas peças ${ }^{6}$ expostas no Núcleo de Arqueologia do Solar Condes de Resende. Trata-se de dois pratos, um de produção focense (GUIMARÃES, 1998, p. 556) e outro de produção africana (GUIMARÃES, 1995, p. 303), com motivos decorativos com clara conotação cristã.

\section{AS CERÂMICAS FINAS TARDIAS DO BOM JESUS DE GAIA}

Como referimos, o nosso estudo, realizado em contexto de estágio no Solar Condes de Resende, consistiu na análise de um conjunto de fragmentos de cerâmica de produções finas tardias, correspondentes a sigillatas de origem africana, focense e hispânica cerâmicas cinzentas tardias de fabrico regional (GUIMARÃES, 1995). Para as produções de sigillata foram contabilizados um total de 193 fragmentos (ver Histograma 1). O fabrico foceense é o mais presente, com o correspondente a $41 \%$ dos fragmentos de Sigillata.

Como se observa no Histograma 1 as produções hispânicas estão pouco representadas, o que poderá estar associado à cronologia de ocupação do local, pois aponta-se que o edifício tenha sido destruído em finais do séc.VI coincidente com o final desta produção (GUIMARÃES, 1995). Também a localização geográfica, junto à foz do rio Douro, poderá explicar a maior presença de produções orientais que chegaram por via marítima.

Além das produções de sigillata, existe ainda um

5. Este grupo de cerâmicas cinzentas carece ainda de um estudo mais aprofundado das suas formas comuns, neste estudo apenas nos focamos em algumas formas e fragmentos decorados, dando maior destaque às imitações de DSP.

6. Estas duas peças estão já publicadas e podem ser vistas nas Estampas XXII e XXIII (GUIMARÃES, 1995, pp. 302 e 303) e no catálogo da exposição In Tempore Sueborum. El Tiempo de los Suevos en la Gllaecia (441-585). El primer reino Medieval de Occidente (GUIMARÃES, 2018, pp. 209-2012). conjunto de 650 fragmentos de Cerâmica Cinzenta, composta maioritariamente por formas comuns e um conjunto mais modesto de imitações de cerâmica fina de mesa de época tardia.

A partir dos dados compilados, apresentamos a catalogação dos fragmentos mais relevantes de cada uma das produções e respetivas formas.

\section{TERRA SIGILLATA AFRICANA TARDIA}

Esta cerâmica fina de mesa, teve um período de produção consideravelmente vasto. Começa em meados do séc. II e termina por volta do séc. VI. Os seus centros produtores situam-se na província da África Proconsular, um território atualmente abrangido pelo norte da Tunísia (BELTRÁN LLORIS,199o).

Neste estudo apenas documentamos as produções tardias, dos fabricos C e D (HAYES, 1972). O fabrico C está representado pelo tipo Hayes 56 da segunda fase de produção (finais séc. IV/1 $1^{\underline{a}}$ metade do séc. V) e pelos tipos 83 e $85 \mathrm{~B}$ da terceira fase de produção (c. 430 a inícios do séc. VI).

O fabrico D está representado pelos tipos Hayes 91A, 93 B, 97 e 104A, todos de uma segunda fase produtiva na sua versão mais comum, datadas dos séculos VI a VII. Apresentam uma pasta de cor laranja/ avermelhada de textura grosseira. $\mathrm{O}$ engobe, semi-lustroso, é muito polido e macio. A superfície externa, não engobada, é ligeiramente rugosa.

A decoração estampada é a mais utilizada, geralmente impressa no fundo interno; os motivos decorativos variam: cruzes, pequenos animais e figuras antropomórficas. Exemplo disto, é o prato do tipo Hayes 104A onde figura uma cruz latina filigranada, com três cordeiros a circundá-la (GUIMARÃES, 1998, p. 551).

Foram ainda identificados fragmentos de lucerna do fabrico D de forma indeterminável (Figura 2).

\section{TERRA SIGILLATA FOCENSE}

A Terra Sigillata Foceense tem, como o próprio nome indica, a sua origem na Foça, uma pequena região do oeste da atual Turquia, situada entre Esmirna e Pérgamo. Foi amplamente difundida no Mediterrâneo Oriental, entre inícios do séc. V até meados do séc. VII, mas também nas costas mais ocidentais do império (DELGADO, 1988, p. 38).

Trata-se de uma cerâmica com fabrico uniforme, com pastas de grãos finos, com partículas brancas 
de calcite. Estas pastas possuem cores bastante homogéneas, variando entre o vermelho, vermelho-alaranjado, vermelho escuro ou acastanhado, oxidantes que podiam chegar aos $1000^{\circ} \mathrm{C}$ (HAYES, 1972, p.324). O engobe cobre toda a superfície da peça, conferindo-lhe um tom mate, por vezes com brilhos levemente metalizados.

Conhecem-se dois tipos de fabrico. Numa primeira fase são peças menos cozidas, consequentemente mais brandas, o que lhe confere cores mais alaranjadas e engobe menos aderente. Na segunda fase, as peças são cozidas a altas temperaturas, ficando a pasta mais dura, com cores vermelhas acastanhadas, a vermelho púrpura.

O reportório de formas é modesto, apenas se conhecem 10 formas (HAYES, 1972), das quais a mais comum é a forma 3. Esta segunda fase de produção caracteriza-se por possuir os bordos enegrecidos, conferindo-lhes uma cor exterior sépia ou mesmo acinzentada (DELGADO, 1992). Na Igreja do Bom Jesus esta foi a forma recuperada tendo-se identificado distintas variantes: $3 \mathrm{~A},{ }_{3} \mathrm{C},{ }_{3} \mathrm{E}, 3 \mathrm{~F}$ e $3 \mathrm{G}$, sendo que a mais comum é a forma ${ }_{3} \mathrm{~F}$ (DELGADO, 1988 , p. 38$)$.

No que toca à decoração destaca-se o uso de guilloché 7 aplicado na superfície, o tipo de decoração mais utilizado, mais concretamente na superfície externa dos bordos da forma 3 (DELGADO, 1988, p. 38 ). Foram também recuperados alguns fundos desta forma com decoração estampada, nomeadamente cruzes e monogramas como é o caso de um conjunto de fragmentos de sigillata foceense expostos no Núcleo Museológico de Arqueologia (GUIMARÃES, 1998, p. 552) (Figura 3).

\section{TERRA SIGILLATA HISPÂNICA TARDIA}

A Terra Sigillata Hispânica Tardia fabricada nos vales do Ebro e Douro, difundiu-se amplamente por toda a Península Ibérica, especialmente no norte peninsular, (BÉLTRAN LLORIS, 1990, p. 111).

Como referimos, nas escavações realizadas na igreja do Bom Jesus Gaia foram encontrados alguns fragmentos de Sigillata Hispânica Tardia, ainda que notoriamente em menor número em comparação com

7. É um motivo decorativo que é obtido através de um instrumento com duas, três ou quatro series de entalhes, capazes de produzir uma larga banda de decoração de uma só vez (HAYES, 1972, p. 329). outras cerâmicas finas, tendo-se apenas identificado as formas Hisp. 27 e Hisp. 68. Estas formas possuem um fabrico típico do Vale do Ebro. Caracterizam-se por possuir um engobe muito poroso e fino, com pastas de cores alaranjadas e avermelhadas, abandonando as pastas calcárias, com baixa percentagem de cálcio (BÉLTRAN LLORIS, 1990, p. 118). Não tendo sido identificados produções do Vale do Douro.

Na parte decorativa, os motivos iam de encontro aos produzidos até então pelos fabricos anteriores, com motivos florais, figuras antropomórficas e zoomórficas, estando presentes nos fragmentos da igreja do Bom Jesus de Gaia, apenas motivos decorativos obtidos por incisões (Figura 4).

\section{CERÂMICA CINZENTA TARDIA}

Nestas escavações foram recuperados 649 fragmentos de Cerâmica Cinzenta, que numa pequena parte imitam ou se inspiram em outros tipos de produção tardios, em sua maioria nas DSP (Derivadas de Sigillata Paleocristã), de origem gálica. Cronologicamente estas produções datam dos finais do séc. $\mathrm{V}$ a inícios do séc. VI, prolongando-se até épocas alti-medievais (DELGADO; MORAIS, 2009, p. 61).

Caracterizam-se por possuir pastas de cores cinza, com presença abundante de desengordurantes; as superfícies são alisadas e, por vezes, polidas. Estas foram fabricadas em ambiente redutor e sujeitas a altas temperaturas, que podem variar entre $900^{\circ} \mathrm{e}$ 1100으 (RIGOIR, 1968, pp. 195-196).

O espectro de formas identificadas é pouco diversificado, correspondendo a imitações de Terra Sigillata Africana, (forma Hayes 59B), e imitações de DSP, (formas Rigoir 3A e 29). São, todavia, mais abundantes as formas de cerâmica comum.

Quanto à decoração, predominam as decorações estampadas, utilizando como motivos decorativos as rosetas e os padrões reticulados. (RIGOIR, 1960, pp. 36-39) (Figura 5).

\section{O VIDRO TARDO ANTIGO}

Na igreja de Bom Jesus de Gaia a presença de fragmentos de vidro é vasta com um total de 1549 fragmentos recolhidos de vários tipos de vidro desta intervenção. No entanto, na nossa análise, apesar de nos estratos superiores ser possível classificar alguns fragmentos como vidro tardio, iremos focar-nos apenas nos fragmentos retirados do estrato 03 , 
objetivamente por dois motivos, o primeiro por ser aquele com maior número de fragmentos, e segundo por estarem diretamente associados com as sigillatas, ou seja, relacionados com o nível paleocristão da intervenção.

Exatamente como a cerâmica tardia, a maior quantidade de vidro antigo foi retirada de uma zona compreendida entre os muros $\mathrm{M}_{1}$ e M2 das ruínas paleocristãs. Gonçalves Guimarães sugere que esta zona seria uma zona de banquete ou copa, ou seja, uma área doméstica do edifício, atentando ao tipo de materiais ali presentes (GUIMARÃES, 1995, p. 136). Estaria coberta por um telhado abatido, anteriormente mencionado, que separava o estrato 02 do estrato 03. Porém, alguns fragmentos de vidro deformados demonstram que foram submetidos a altas temperaturas, podendo concluir-se que houve destruição física do edifício seguida de incêndio, ainda que parcelar. $\mathrm{O}$ que fez cair o telhado foram os batólitos que derrubaram o edifício, o incêndio terá vindo a seguir (Figura 6).

Neste estrato 03, foram recolhidos 519 fragmentos de vidro de duas colorações distintas (ver histograma 3), para as quais atribuimos as denominações Verde azulado e Amarelo acastanhado. Quanto a atribuição destas terminologias seguimos a tabela de cores apresentada por Mário Cruz (CRUZ, 2009, p. 93), que por sua vez é uma interpretação das terminologias atribuidas até então seguindo um quadro de apróximação cromática de código de cor Pantone.

Não sendo possível a análise quimica dos fragmentos, as distinções foram feitas maioritáriamente por apróximação da cor e das formas destes mesmos fragmentos.

Objetivamente, o número minimo de peças apróximar-se-à do número de fundos encontrados neste estrato, cerca de 20. Os fundos encontram-se num estado menos fragmentado, na sua maioria, não apresentando colagens uns com os outros e por esse motivo se singularizam em relação aos outros fragmentos, que apesar de estarem em número muito superior o seu estado de fragmentação impede-os de serem viáveis neste tipo de contagem.

Quanto ao aspeto formológico, foram detetadas semelhanças com as formas do catálogo de Isings, 41A, 97A, 111 e a forma 112, sendo que esta última é a forma já tinha sido anteriormente identificada por Gonçalves Guimarães.

A forma Isings 41A caracteriza-se como sendo uma tigela de paredes retas, bastante similar à forma 22 do mesmo catálogo. Tem uma base recortada e um bordo grosso e dobrado (ISINGS, 1957 p. 57).

O prato Isings $97 \mathrm{~A}$, um prato circular baixo de base sólida, é um tipo de peça atribuida ao séc. II inicios do séc. III, no entanto pela sua versatilidade manteve-se em utilização até tempos muito mais recentes (ISINGS, 1957 pp. 116-117).

Um dos fragmentos de bordo aproxima-se da forma Isings 111, um cálice de caule, com algumas variantes, um tipo de forma que se manteve em uso por toda a Europa e Próximo Oriente até tempos medievais (ISINGS, 1957 pp. 139-140).

Destacamos ainda a taça com asas, designada como Taça nํำ (GUIMARÃES, 1995, p.316), com uma asa, de bordo espesso e base tubular, que apesar de incompleta, apresenta semelhanças com a forma Isings 112 .

Finalizando, ao contrário dos fabricos cerâmicos, nos fragmentos de vidro analisados não foram identificados quaisquer motivos decorativos (Figura 7).

\section{CONCLUSÃO}

As escavações feitas na igreja do Bom Jesus de Gaia trouxeram um conjunto de informações importantes sobre a povoação que ocupava aquele local no séc.VI através do espólio paleocristão levantado. É assim de realçar a importância do estudo das produções utilitárias de cerâmica e vidro tardias aqui encontradas. Neste estudo pudemos corroborar a cronologia proposta para a destruição do edifício paleocristão, por volta de 580 (GUIMARÃES, 1995, p. 135). A quantidade de cerâmica importada é notável, com destaque para as produções foceenses, revelando a importância económica da região do curso terminal do Rio Douro. Assim o documentam as produções finas de cerâmica tardia, as sigillatas de origem africana, focense e hispânica a par das cerâmicas cinzentas tardias, cronologicamente enquadrados nos séc. V/VI d.C.

Também a análise de forma do vidro permitiu identificar semelhanças com formas utilizadas em séculos anteriores ao séc. VI, como também ser evidência fisica da destruição violenta do edificio paleocristão. As intervenções arqueológicas que se têm vindo a realizar no municipio, de uma maneira ou de outra, ajudam numa construção do passado da região, neste caso o estudo de um conjunto particular de materiais utilitários como uma mais valia nessa construção. Em suma procuramos ter contribuído para o conhe- 
cimento da antiguidade tardia no território gaiense e dar a conhecer as produções de vidro e cerâmicas tardias da igreja do Bom Jesus de Gaia.

\section{BIBLIOGRAFIA}

BERNAL CASSOLA, Dario; RIBERA I LACOMBA, Albert (2008) - Cerámicas hispanorromanas. Un estado de la cuestión. Vol I e II, Universidad de Cádiz, Cadíz.

BELTRAN LLORIS, Miguel (1997) - Guia de las cerámicas romanas., Libros Pórtico, Zaragoza.

CRUZ, Mário da (2009) - O vidro no Noroeste Peninsular, Vol. 1-2, Tese de Doutoramento apresentada na Universidade do Minho, Braga.

DELGADO, Manuela (1988) - Contribuição para o estudo das cerâmicas romanas tardias do Médio Oriente, Cadernos de Arqueologia, série II, 5, pp. 35-49.

DELGADO, Manuela (1992) - Cerâmicas Romanas Tardias de Mértola Originarias do Médio Oriente, Arqueologia Medieval, nำ1, Edições Afrontamento, Porto.

DELGADO, Manuela; MORAIS, Rui (20o9) - Guia das cerâmicas de produção local de Bracara Augusta, CITCEM, Braga.

FOY, Danièle (1995) - Le verre de l'antiquité tardive et du haut moyen age: typologie, chronologie, diffusion, Musée Archéologique Departmental du Val d'Oise.

GASPAR, Alexandra (20oo) - Contribuição para o estudo das cerâmicas dos séculos V/VI de Braga. Tese de Mestrado apresentada na Universidade do Minho, Braga.

GUIMARÃES, J. A. Gonçalves (1989) - Escavações Arqueológicas na Igreja do Bom Jesus de Gaia, Boletim da Associação Cultural Amigos de Gaia, ํํ 28, dezembro, Vila Nova de Gaia.

GUIMARÃES, J. A. Gonçalves (1992) - Museologia Arqueológica em Vila Nova de Gaia. Boletim da Associação Cultural Amigos de Gaia, junho, Vila Nova de Gaia, pp. 3-7.

GUIMARÃES, J. A. Gonçalves (1995) - A Colecção Marciano Azuaga e a sua bibliografia. Prefácio a PEREIRA, António Sérgio dos Santos-Mundurukús, Carajás e outros índios do Brasil na Colecção Marciano Azuaga. Câmara Municipal de Vila Nova de Gaia - Casa Municipal de Cultura/ Solar Condes de Resende, Vila Nova de Gaia, pp. 5-14.

GUIMARÃES, J. A. Gonçalves (1995) - Gaia e Vila Nova Na Idade Média - Arqueologia de uma Área Ribeirinha. Universidade Portucalense, Porto.

GUIMARÃES, J. A. Gonçalves (200o) - Um século de Arqueologia em Vila Nova de Gaia, Almadam, II Série, no 9. outubro, pp. 155-168.
GUIMARÃES, J. A. Gonçalves (2010) - Os Romanos em Gaia, Boletim da Associação Cultural Amigos de Gaia, ํํㄱㅇ, junho, Vila Nova de Gaia.

GUIMARÃES, J. A. Gonçalves (2018) - O edificio de tradição roamana sob a igreja do Bom Jesus de Gaia (Vila Nova de Gaia - Portugal) destruído nos últimos dias do reino dos Suevos, LÓPEZ QUIROGA, coord. (2018) - In Tempore Sueborum. El Tiempo de los Suevos en la Gllaecia (441-585). El primer reino Medieval de Occidente, Volumen de Estudios. Ourense: Deputacion Provincial, pp. 209-212.

GUIMARÃES, J. A. Gonçalves (2019) - O edificio de tradição roamana sob a igreja do Bom Jesus de Gaia destruído nos últimos dias do reino dos Suevos, Revista de Portugal, ํํ⒗ Novembro, pp. 16-24.

HAYES, J.W. (1972), Late Roman Pottery - A Catalogue of Roman Fine Wares, The British School at Rome, London.

HAYES, J.W. (1980) - Suplement to Late Roman Pottery, The British School at Rome, London.

ISINGS, Classina. (1957) - Roman Glass from dated Finds, Archaeologica Traiectina, Jacarta.

MAYET, François (1975) - Les céramique à paroi fines dans la Péninsule Ibérique. Diffusion E. de Boccard, Paris.

MEZQUIRIZ, Maria Angeles (1985) - Terra sigillata hispánica, In Atlante delle Forme Ceramiche (Ceramica Fine Romana Nel Bacino Mediterraneo. Enciclopédia Dell'arte Antica Clássica), vol. II, Roma, pp. 97-174.

MOREIRA, Álvaro de Brito (1997) - Vidros Romanos do Noroeste Português. Estudos Monográficos de Tomgobriga e Alvarelhos, Estudos Monográficos de Tomgobriga e Alvarelhos, $1,2^{\underline{a}}$ série, Museu Municipal Abade Pedrosa, Santo Tirso; 13-82.

RAMOS, Joaquim Filipe (2017) - Estágio Solar Condes de Resende. Contributo para os estudo das cerâmicas finas tardias da igreja do Bom Jesus de Gaia. Relatório de Estágio para obtenção de Mestrado apresentado na FLUP, Porto.

RIGOIR, Jacqueline (1960) - La Céramique Paleochrétiene Sigillée Grise, In Provence Historique, tome X, fasc. 42, La Pensée Universitaire, Aix-en-Provence, pp. 1-93.

RIGOIR, Jacqueline (1968) - Les Sigillées Paléochrétiennes grises et orangées, Gallia, XXVI, fasc. 1, Paris, p. 177-244.

SILVA, António Manuel S. P.; CARVALHO, Teresa P. (2014) - Originalidade e tradição clássica na cerâmica local e regional tardo-antiga do castelo de Crestuma (V. N. Gaia, Portugal), in MORAIS, R.; FERNANDÉZ, A.; SOUSA, M. J. (eds.) - As produçôes cerâmicas de imitação na Hispania. S.1. [Porto-Madrid]: Faculdade de Letras da Universidade do Porto - Ex Officina Hispana II, pp. 381-396. 


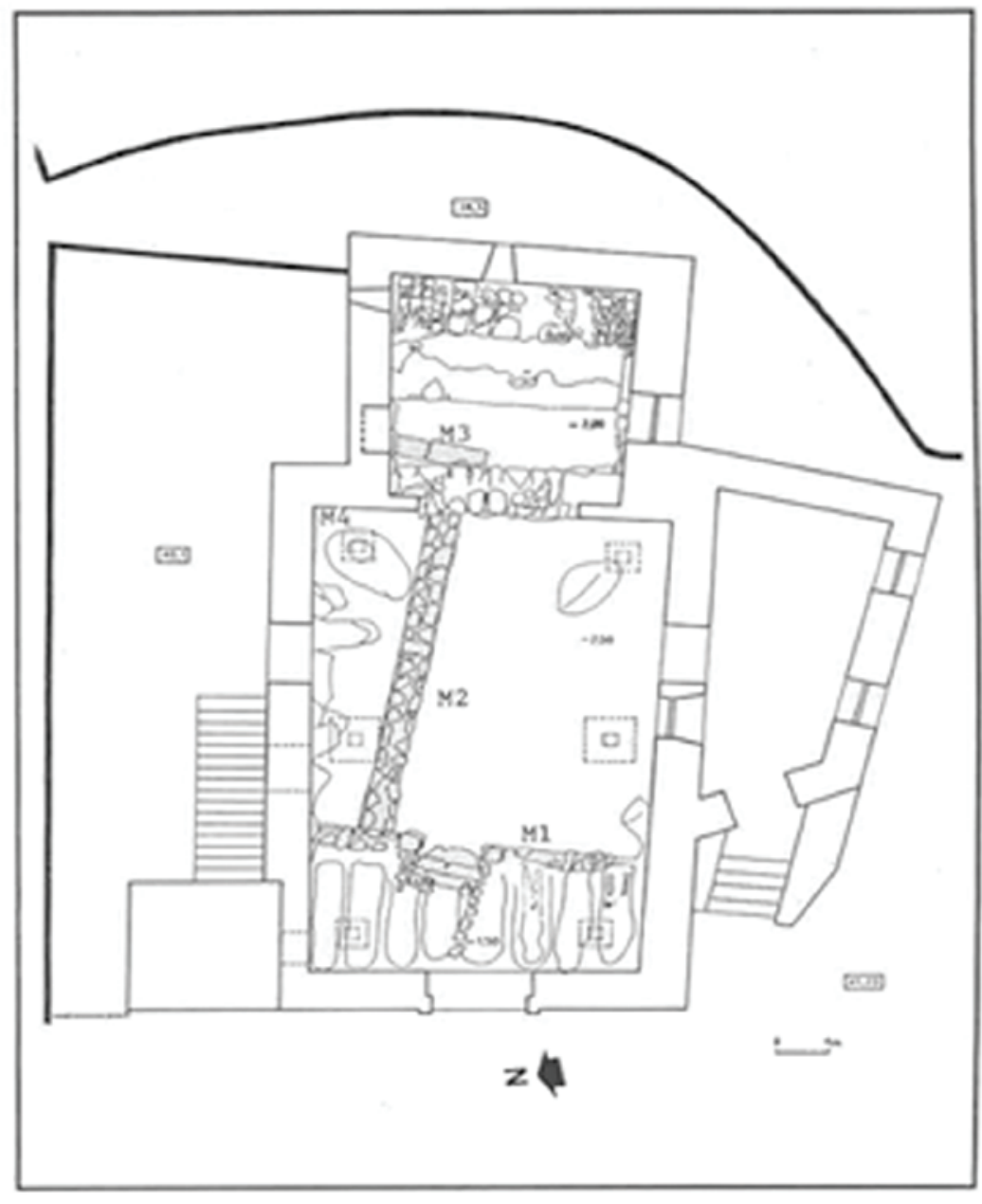

Figura 1 - Planta da igreja de Gaia: área escavada. Fonte: Estampa XI (GUIMARÃES, 1995, p. 291) 


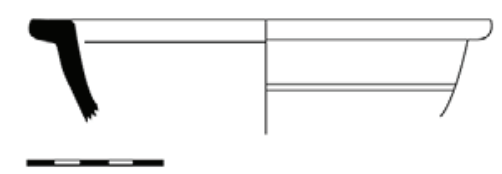

1

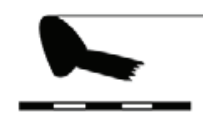

3

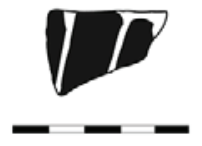

5

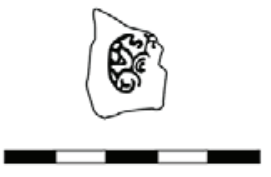

9

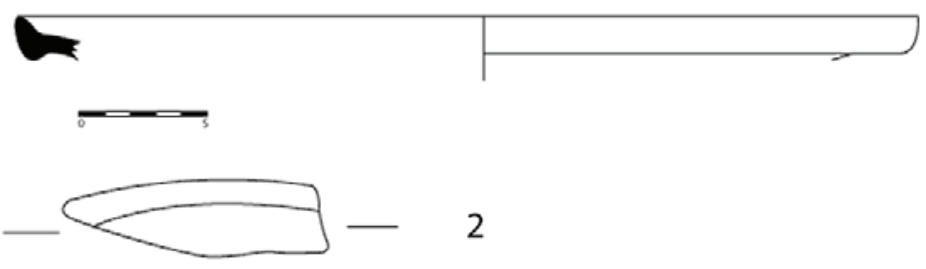

4
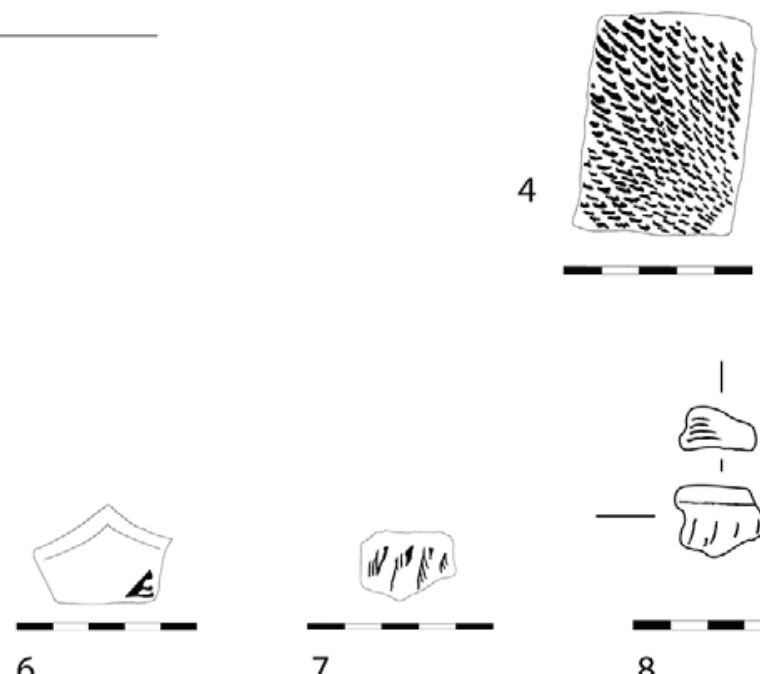

7

8

Figura 2 - Conjunto de Sigillatas Africanas Tardias: 1 - fragmento de bordo de tigela, forma Hayes 93B, 450-530 d.C.; 2 - fragmento de bordo de prato, forma Hayes 104A, 530-580 d.C; 3 - fragmento de bordo de prato, forma Hayes 104A, 530-580 d.C; 4-fragmento de fundo tigela, forma Hayes 91A, 450-530 d.C.; 5-fragmento de prato, forma Hayes 56, de cronologia indeterminada; 6 - fragmento de bordo de tigela, forma Hayes 97, decorada na parte interior do bordo, 490-540 d.C.; 7 - fragmento de tigela, forma Hayes 83A, datada dos inícios do séc.V d.C.; 8 - fragmento de bordo de tigela, forma Hayes85B, datável da segunda metade do séc.V d.C.; 9 - fragmento de lucerna de fabrico D, datavél do séc.V, de forma indeterminada; 10 - fragmento de lucerna de fabrico D, datavél do séc.V, de forma indeterminada. Escalas apresentadas de $5 \mathrm{~cm}$. 


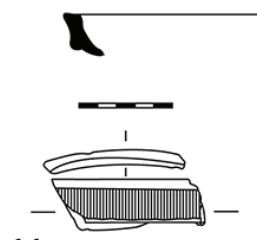

11
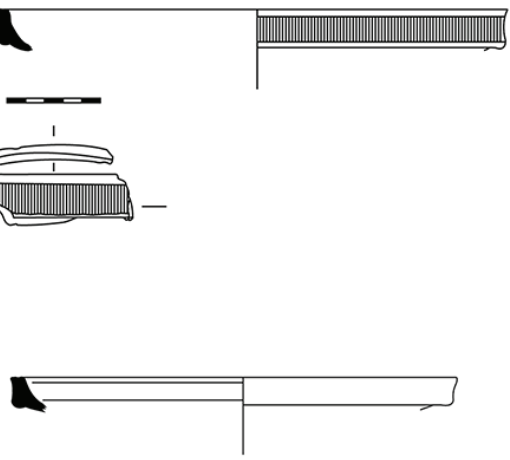

13
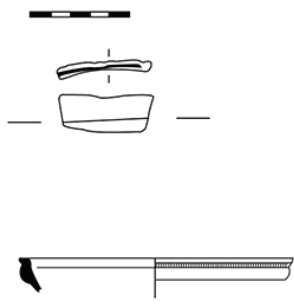

15

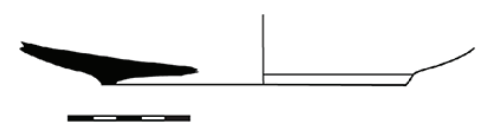

18
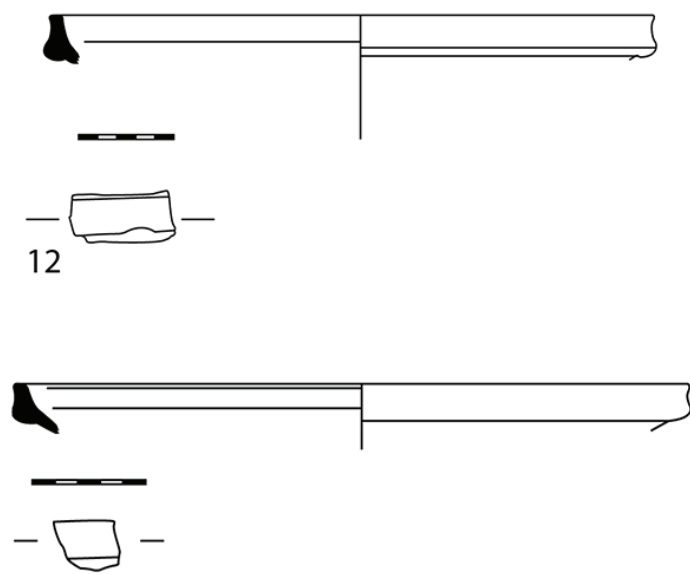

14
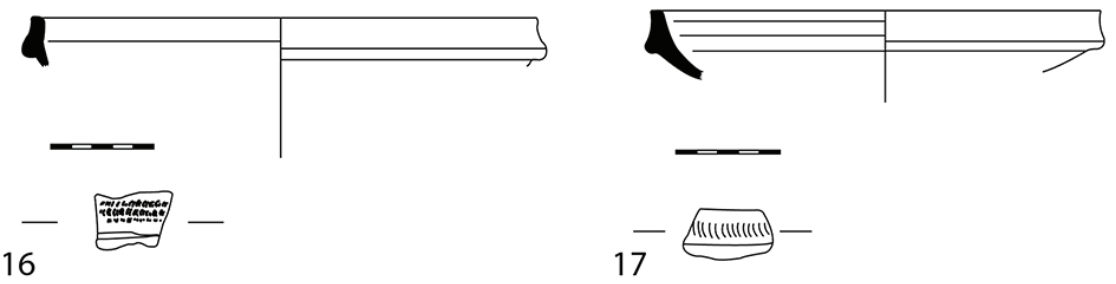

17
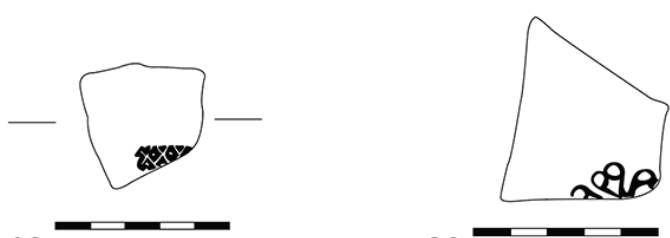

19

20

Figura 3 - Conjunto de Sigillatas Focenses Tardias: 11 - fragmento de bordo de prato/taça, forma Hayes 3A, com decoração de Guilhóche, datado de inícios do séc. V d.C.; 12 - fragmento de bordo de prato/taça, forma Hayes 3 G, segundo quartel do séc. VI d.C.; 13 - fragmento de bordo de prato/taça, forma Hayes 3F, inícios do séc. VI d.C.; 14 - fragmento de bordo de prato/taça, forma Hayes 3 F, inícios do séc. VI d.C.; 15 fragmento de bordo de prato/taça, forma Hayes ${ }_{3} C$, meados do séc. V d.C.; 16 - fragmento de bordo de prato/taça, forma Hayes 3F, com decoração de Guilhóche, inícios do séc. VI d.C.; 17 - fragmento de bordo de prato/taça, forma Hayes ${ }_{3} \mathrm{C}$, meados do séc. V d.C.; 18 - fragmento de pé de prato/taça, forma Hayes $3 \mathrm{~A}$, inícios do séc. V d.C.; 19 - fragmento de bordo de prato/taça, forma Hayes 3F, com decoração estampada (Carimbo de lozangulos com circulos no centro decoração Late Roman) inícios do séc. VI d.C.; 20 - fragmento de fundo de prato/taça, com decoração estampada, forma Indeterminada. Escalas apresentadas de $5 \mathrm{~cm}$. 


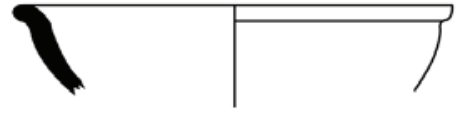

21

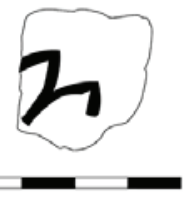

23
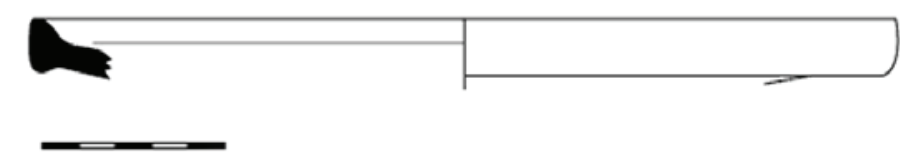

22

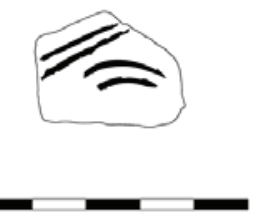

24

Figura 4 - Conjunto de Sigillatas Hispânicas Tardias: 21 - fragmento de bordo de taça, forma Hisp. 27, finais séc. V d.C.; 22 fragmento de bordo de prato, forma Hisp. 68, finais do séc. V d.C.; 23 - fragmento decorado com motivos florais, forma indeterminada; 24 - fragmento decorado com incisões, forma indeterminada. Escalas apresentadas de $5 \mathrm{~cm}$. 

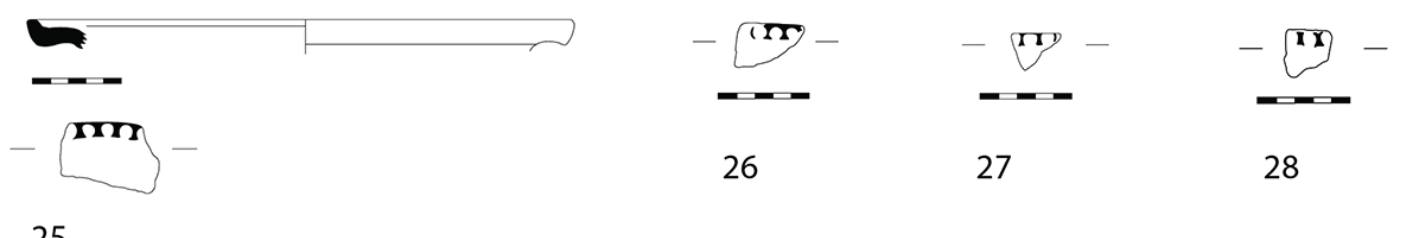

25

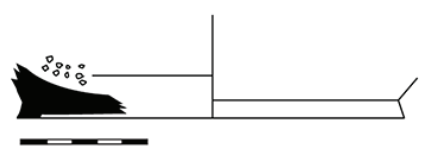

29
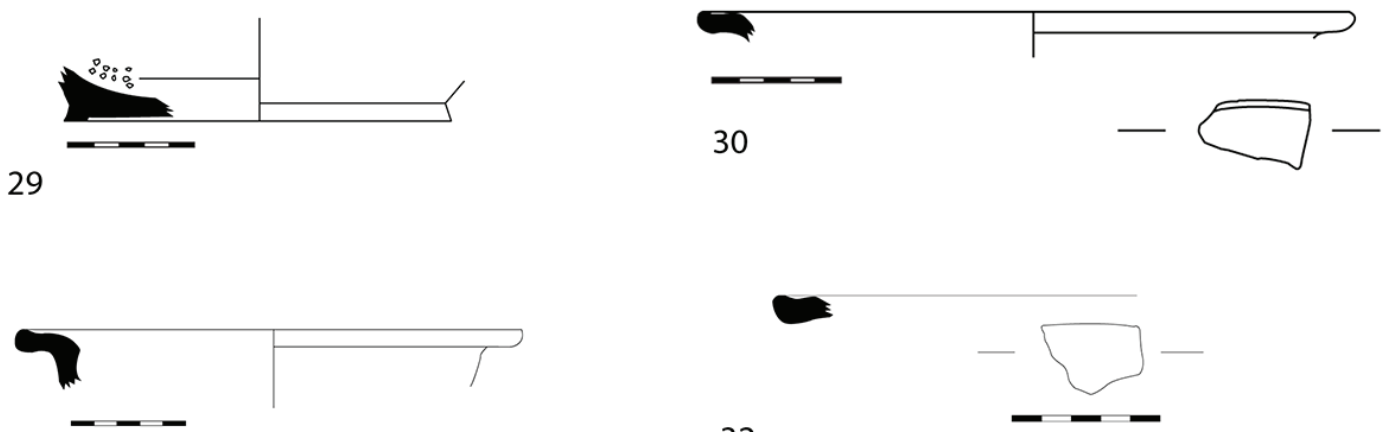

31
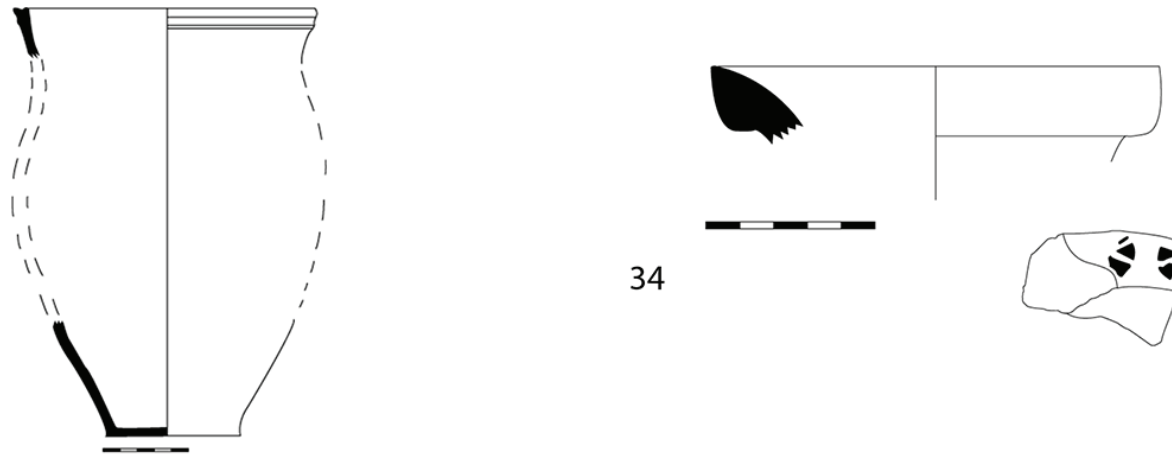

34

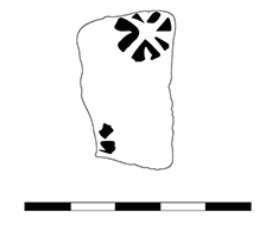

36

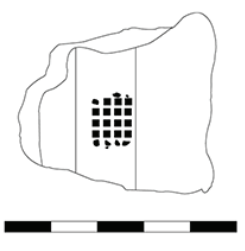

37

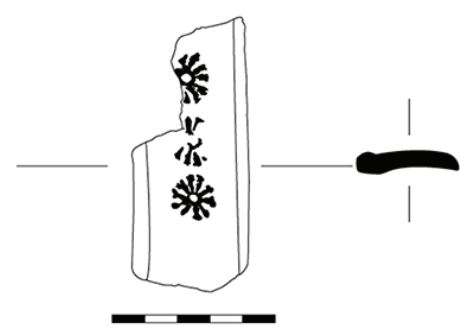

38

Figura 5 - Conjunto de Cerâmicas Cinzentas Tardias: 25 - fragmento de bordo de tigela, imitação de forma Rigoir 3A, 450530 d.C.; 26 - fragmento de bordo de tigela, imitação de forma Rigoir 3A, 450-530 d.C.; 27 - fragmento de bordo de tigela, imitação de forma Rigoir 3A, 450-530 d.C.; 28 - fragmento de bordo de tigela, imitação de forma Rigoir 3A, 450-530 d.C.; 29 - fragmento de pé/fundo, imitação forma Rigoir 29, séc. V/VI; 30 - fragmento de bordo de tigela imitação de forma Hayes 59B, séc. V/VI; 31 - fragmento de bordo de tigela imitação de forma Hayes 59B, séc. V/VI; 32 - fragmento de bordo de tigela imitação de forma Hayes 59B, séc. V/VI; 33 - Pote de forma comum de cerâmica cinzenta tardia; 34 - fragmento de bordo de forma comum, decorado com rosetas na face exterior do bordo; 35 - fragmento de fundo de forma indeterminada, decorado com rosetas estampadas e duas linhas de entalhe a circundar, sendo uma linha curvilinea e a outra serpenteada; 36 - fragmento de forma indeterminada, decorado com rosetas estampadas; 37 - fragmento de forma indeterminada, com grelha reticulada estampada, similar à decoração Hayes 67A; 38 - fragmento de asa de forma indeterminada, com decoração estampada, rosetas na face exterior da asa. Escalas apresentadas de $5 \mathrm{~cm}$. 


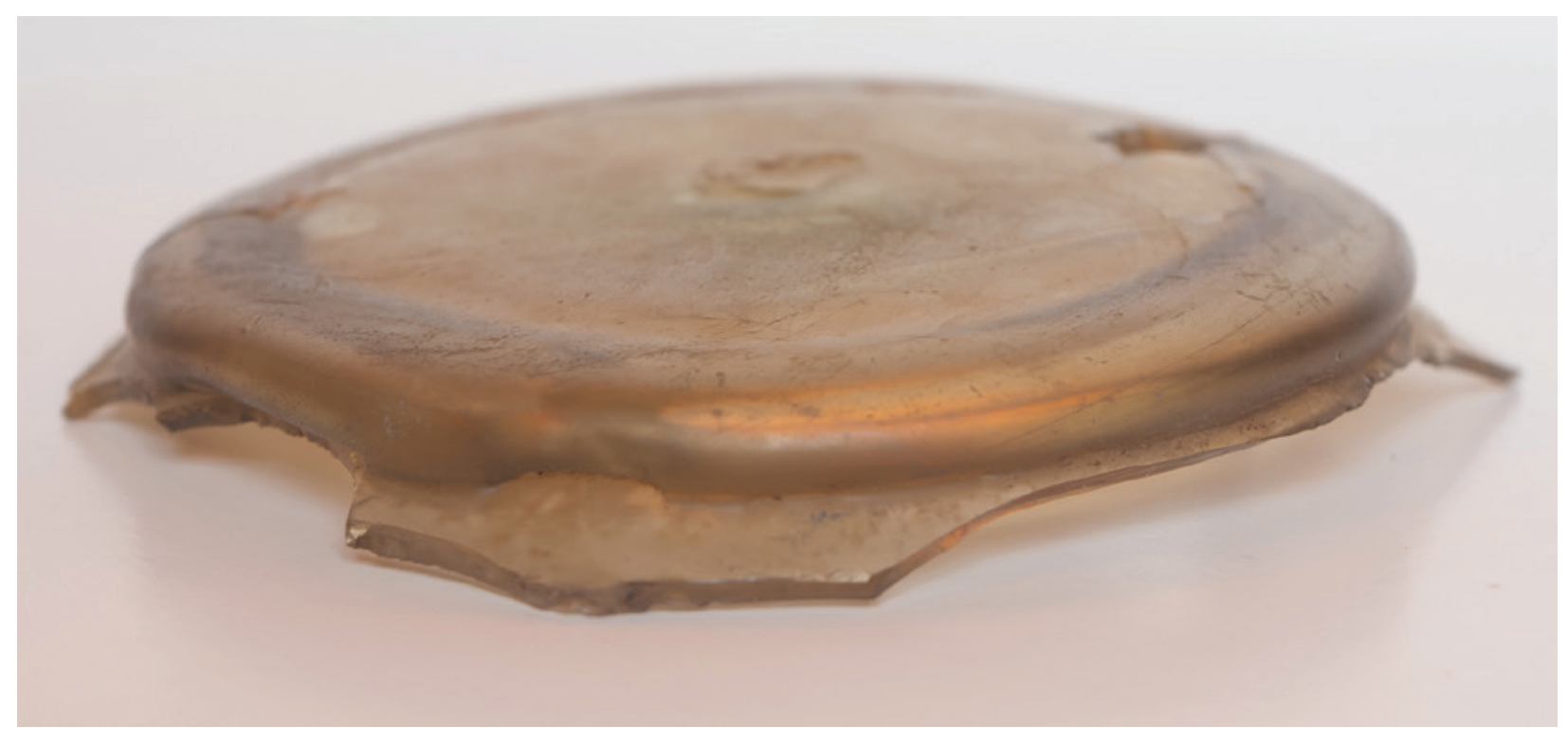

Figura 6 - Fragmento de fundo deformado forma Isings 47A, com cerca de $10 \mathrm{~cm}$ diâmetro de base.

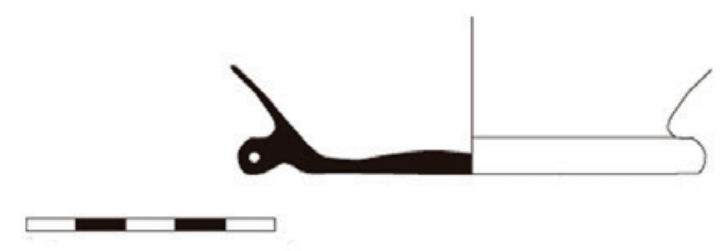

39

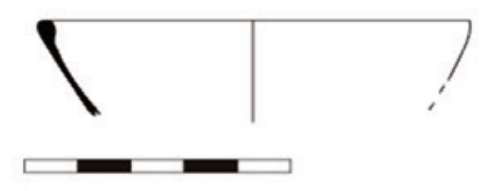

40

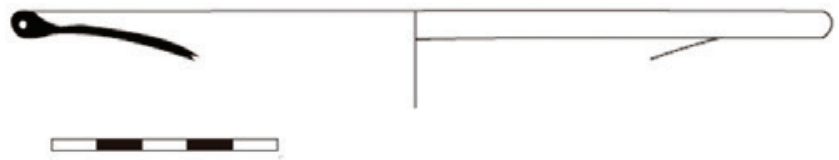

41

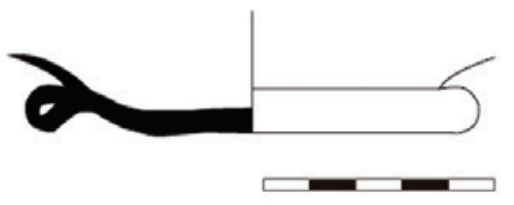

42

Figura 7 - Conjunto de Vidro tardo antigo: 39 - fragmento de fundo de tigela, forma Isings 41A; 40 - fragmento de bordo de taça, forma Isings 111; 41 - fragmento de bordo de prato, forma Isings 97A; 42 - fragmento de fundo de prato, forma Isings $97 \mathrm{~A}$. 


\section{SIGILLATAS TARDIAS DO BOM JESUS DE GAIA}

Bordos Pés/Fundos @ Outros

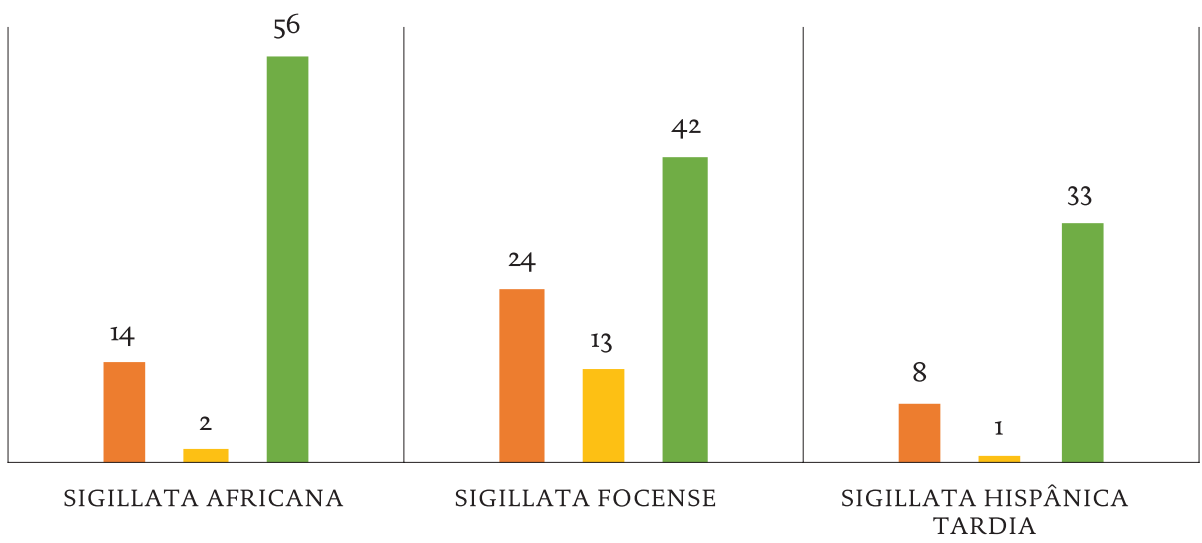

Histograma 1 - Número de fragmentos de sigillata por fabrico.

IGREJA DO BOM JESUS DE BRAGA

Variantes da Forma 3 Hayes

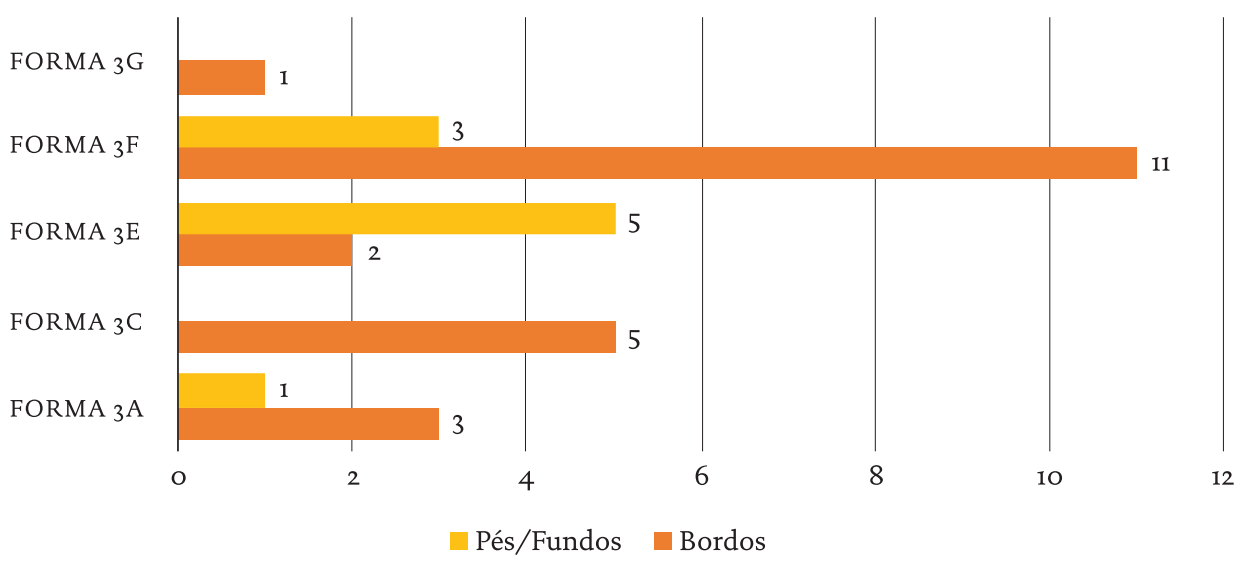

Histograma 2 - Número de fragmentos das variantes de Sigillata Foceense forma 3 de Hayes.

FRAGMENTOS DE VIDRO DO ESTRATO O3 IBJG

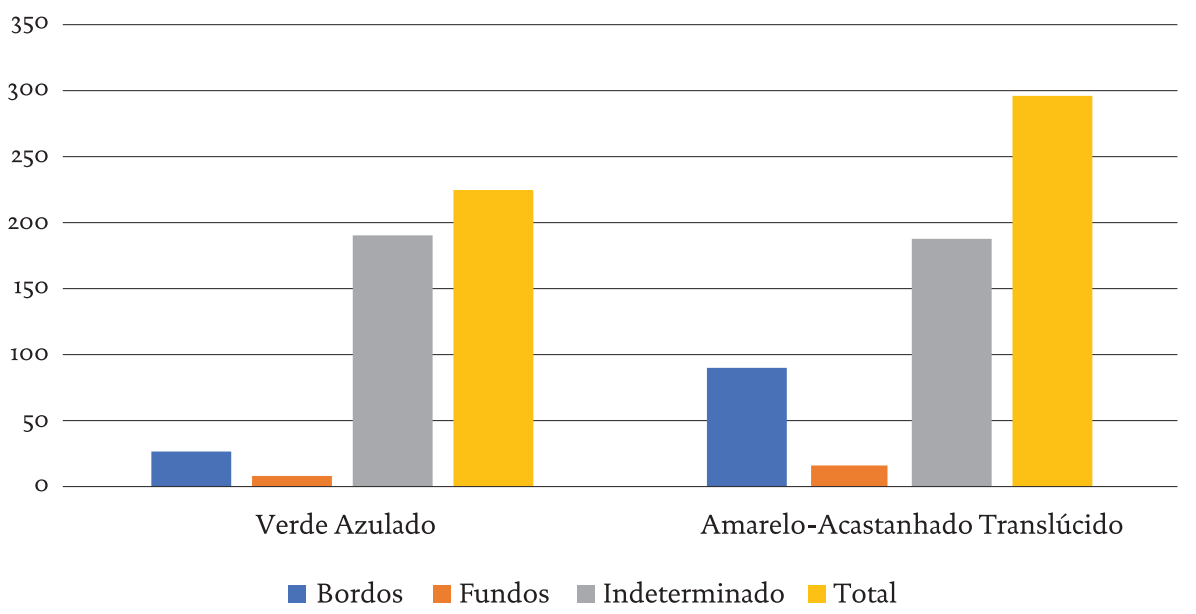

Histograma 3 - Fragmentos de vidro paleocristão do estrato o3 da igreja do Bom Jesus de Gaia. 


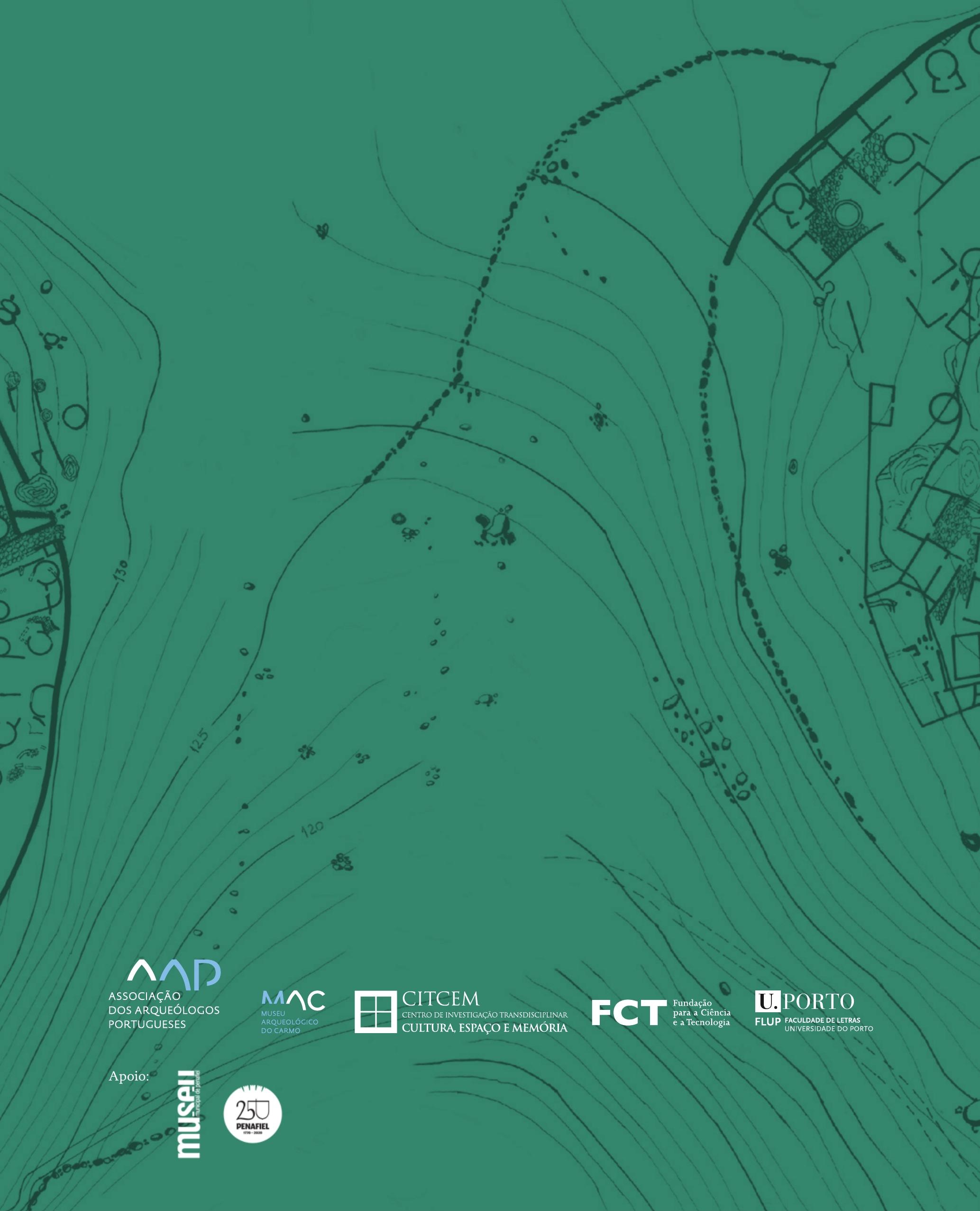

